ARTICLE

\title{
Unusually high soil nitrogen oxide emissions influence air quality in a high-temperature agricultural region
}

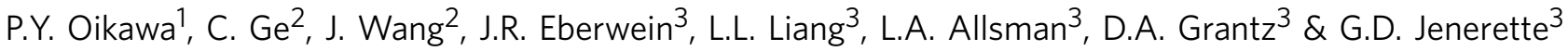

Fertilized soils have large potential for production of soil nitrogen oxide $\left(\mathrm{NO}_{x}=\mathrm{NO}+\mathrm{NO}_{2}\right)$, however these emissions are difficult to predict in high-temperature environments. Understanding these emissions may improve air quality modelling as $\mathrm{NO}_{x}$ contributes to formation of tropospheric ozone $\left(\mathrm{O}_{3}\right)$, a powerful air pollutant. Here we identify the environmental and management factors that regulate soil $\mathrm{NO}_{x}$ emissions in a high-temperature agricultural region of California. We also investigate whether soil $\mathrm{NO}_{x}$ emissions are capable of influencing regional air quality. We report some of the highest soil $\mathrm{NO}_{\mathrm{x}}$ emissions ever observed. Emissions vary nonlinearly with fertilization, temperature and soil moisture. We find that a regional air chemistry model often underestimates soil $\mathrm{NO}_{\mathrm{x}}$ emissions and $\mathrm{NO}_{\mathrm{x}}$ at the surface and in the troposphere. Adjusting the model to match $\mathrm{NO}_{\mathrm{x}}$ observations leads to elevated tropospheric $\mathrm{O}_{3}$. Our results suggest management can greatly reduce soil $\mathrm{NO}_{x}$ emissions, thereby improving air quality.

\footnotetext{
${ }^{1}$ Department of Environmental Science, Policy and Management, University of California, Berkeley, California 94720, USA. ${ }^{2}$ Department of Earth and Atmospheric Sciences, University of Nebraska-Lincoln, Lincoln, Nebraska 68588, USA. ${ }^{3}$ Department of Botany and Plant Sciences, University of California, Riverside, California 92521, USA. Correspondence and requests for materials should be addressed to P.Y.O. (email: patty.oikawa@gmail.com).
} 
W hile agriculture in high-temperature environments is widespread and will become increasingly prominent in a future warmer climate ${ }^{1}$, the impacts of these systems on air quality are poorly constrained ${ }^{2,3}$. Nitrogen $(\mathrm{N})$ losses to the atmosphere from high-temperature agroecosystems are not well characterized ${ }^{2,4}$ and are likely higher than temperate systems due to the combination of $\mathrm{N}$ fertilization ${ }^{2,5}$, nonlinear temperature dependence of biological processes ${ }^{6}$ and pulsed fluxes in response to irrigation-drying cycles 7 . Soil nitrogen oxide $\left(\mathrm{NO}_{\mathrm{x}}=\mathrm{NO}+\mathrm{NO}_{2}\right)$ is one important form of $\mathrm{N}$ trace gas that can be released from fertilized soils and plays an important role in the formation of tropospheric ozone $\left(\mathrm{O}_{3}\right)$, a toxic air pollutant. Approximately $1 / 4$ of global $\mathrm{NO}_{\mathrm{x}}$ production is derived from soils, mostly from fertilized agriculture; however, estimates of global soil $\mathrm{NO}_{\mathrm{x}}$ emissions vary widely $(9-27 \mathrm{Tg} \text { per year })^{8-10}$. Understanding how soil $\mathrm{NO}_{\mathrm{x}}$ emissions are regulated in hightemperature agroecosystems will help constrain current and future global $\mathrm{NO}_{\mathrm{x}}$ budgets and quantify the human health and ecosystem impacts of fertilized agriculture in a warming world.

The Southwestern United States of America has been experiencing warmer winter temperatures and more frequent heat waves over the past 100 years ${ }^{11,12}$ and is considered to be a climate-change hotspot ${ }^{13}$. The Imperial Valley, CA, is an important agricultural region within the Southwestern United States of America encompassing 200,000 hectares of irrigated agricultural land with air temperatures $>40^{\circ} \mathrm{C}$ in the summer. The Imperial Valley also suffers from poor air quality that regularly exceeds government $\mathrm{O}_{3}$ standards $^{14}$, and experiences the highest rates of asthma hospitalizations in California ${ }^{15}$. To improve air quality in the region, understanding how urban and agricultural sources contribute to $\mathrm{O}_{3}$ formation is necessary. Fossil fuel combustion is likely a dominant source of $\mathrm{NO}_{\mathrm{x}}$ in the region, as there are small cities within the Imperial Valley (for example, El Centro; population $=163,972$ ) and large neighbouring urban areas including Los Angeles, San Diego and Mexicali. However, it is not clear whether agricultural $\mathrm{NO}_{\mathrm{x}}$ emissions significantly increase $\mathrm{O}_{3}$ formation, as $\mathrm{O}_{3}$ chemistry may be $\mathrm{NO}_{\mathrm{x}}$ saturated ${ }^{16}$. On the other hand, if the atmosphere is $\mathrm{NO}_{\mathrm{x}}$ limited, soil $\mathrm{NO}_{\mathrm{x}}$ emissions may enhance $\mathrm{O}_{3}$ formation, as observed in agricultural regions in the Midwestern United States of America ${ }^{17}$. The Imperial Valley is therefore a complex and important location for studying the impact of agriculture on air quality and human health.

Soil $\mathrm{NO}_{\mathrm{x}}$ emissions vary nonlinearly with environmental and land management factors including temperature, fertilization and soil moisture, but these relationships are not well constrained in high-temperature systems. While most studies have detected exponential increases in soil $\mathrm{NO}_{\mathrm{x}}$ emissions with temperature, there are contrasting results concerning high-temperature $\left(>30^{\circ} \mathrm{C}\right)$ responses of soil $\mathrm{NO}_{\mathrm{x}}$ emission ${ }^{18,19}$. Fertilization and $\mathrm{N}$ deposition are known to increase soil $\mathrm{NO}_{\mathrm{x}}$ emissions; however, the majority of studies are conducted at temperatures below $35^{\circ} \mathrm{C}$ (refs 6,20). In addition, fertilization type, amount and application method are known to influence soil $\mathrm{NO}_{\mathrm{x}}$ emissions. Side-injected fertilizers (where fertilizer is injected into the soil versus applied to the top) and splitting fertilization into smaller applications $\left(<100 \mathrm{~kg} \mathrm{Nha}^{-1}\right)$ can limit $\mathrm{NO}_{\mathrm{x}}$ emission; however, these factors have mainly been evaluated in temperate environments ${ }^{5}$. Finally, irrigation and soil moisture are important factors regulating soil $\mathrm{NO}_{\mathrm{x}}$ emissions. In particular, strong pulse $\mathrm{NO}_{\mathrm{x}}$ emission responses to rewetting of soils in high-temperature regions are important ${ }^{21-23}$, yet understudied in managed systems. Therefore, measuring soil $\mathrm{NO}_{\mathrm{x}}$ emissions at high temperatures under different fertilization and soil-moisture conditions is needed to understand the regulation of fluxes, improve management and inform biogeochemical models.
Most chemistry transport models predict soil $\mathrm{NO}_{\mathrm{x}}$ emissions as a function of temperature, soil moisture and ecosystem type, such as in the Yienger and Levy model ${ }^{24}$ (hereafter called YL95). Models often assume optimum temperatures for nitrification and denitrification occur at $20-30^{\circ} \mathrm{C}$ (refs 25,26 ), with soil $\mathrm{NO}_{\mathrm{x}}$ emissions increasing exponentially before hitting a plateau at $30^{\circ} \mathrm{C}($ refs 8,9$)$. Within the YL95 paradigm, agricultural systems are assumed to be wet year-round and are assigned an emission factor associated with fertilization, where $1-2 \%$ of fertilizer applied is lost as $\mathrm{NO}_{\mathrm{x}}$ throughout the growing $\operatorname{season}^{27,28}$. Fertilization and irrigation events are generally not considered pulse events in models and are instead interpreted as elevating emissions at a constant rate throughout a growing season (for example, YL95 and the Weather Research and Forecasting with Chemistry model (WRF-Chem) $)^{29}$ ). Despite updates to YL95 (refs 8,9), uncertainty associated with $\mathrm{NO}_{\mathrm{x}}$ pulse emission events and fertilizer-induced agricultural emissions is large $e^{8,9,23,27}$.

Here we aim to identify the environmental (that is, soil temperature, soil volumetric water content and inorganic $\mathrm{N}$ availability) and management factors (that is, time since fertilization and fertilization application practices) that regulate soil $\mathrm{NO}_{\mathrm{x}}$ emission, and its impacts on air quality in a hightemperature agricultural region: the Imperial Valley, California. Soil $\mathrm{NO}_{\mathrm{x}}$ emission measurements were conducted using the static chamber technique throughout two growing seasons of a high biomass grass, Sorghum bicolor. We use two N-fertilization experiments to evaluate pulse $\mathrm{NO}_{\mathrm{x}}$ responses to different levels of fertilization (20,50 and $\left.100 \mathrm{~kg} \mathrm{Nha}^{-1}\right)$ and fertilizer application methods (side-injected dry granulated $\mathrm{N}$ versus dissolved $\mathrm{N}$ ). The implications of soil $\mathrm{NO}_{\mathrm{x}}$ fluxes on regional air quality are evaluated using a regional air chemistry model and local and remote sensing measurements of $\mathrm{NO}_{2}$ at the surface and in the troposphere. In these modelling exercises, we aim to test whether the model assumptions are valid for high-temperature environments. Specifically, we evaluate the model's ability to simulate soil $\mathrm{NO}_{\mathrm{x}}$ emissions, surface concentrations of $\mathrm{NO}_{2}$ and tropospheric $\mathrm{NO}_{2}$ columns in the Imperial Valley. We also elevate soil $\mathrm{NO}_{\mathrm{x}}$ emission rates in the model to evaluate the impact of those emissions on regional concentrations of tropospheric $\mathrm{O}_{3}$. We find that soil $\mathrm{NO}_{\mathrm{x}}$ emissions from this site are among the highest ever observed and respond nonlinearly to increases in fertilization, temperature and soil moisture. We also find that a regional air chemistry model often underestimates soil $\mathrm{NO}_{\mathrm{x}}$ emissions, surface $\mathrm{NO}_{2}$ concentrations and tropospheric $\mathrm{NO}_{2}$ columns in the Imperial Valley. Finally, we find that increasing cropland soil $\mathrm{NO}_{\mathrm{x}}$ emissions to match observations leads to elevated surface $\mathrm{O}_{3}$ concentrations.

\section{Results}

Environmental drivers of soil $\mathrm{NO}_{\mathrm{x}}$ emission. Soil $\mathrm{NO}_{\mathrm{x}}$ emissions observed in a high-temperature fertilized agricultural region of the Imperial Valley, CA, ranged between -5 and $900 \mathrm{ng}$ $\mathrm{N} \mathrm{m}^{-2} \mathrm{~s}^{-1}$. The highest $\mathrm{NO}_{\mathrm{x}}$ fluxes (top $10 \%$ ) were observed at temperatures between $27-40^{\circ} \mathrm{C}$ with moderate soil volumetric water content (0.14-0.40) and within 23 days of a fertilization event. The strongest predictor of $\mathrm{NO}_{\mathrm{x}}$ flux across all measurements was days since fertilization $(F=5.32, P<0.0001$; Fig. 1a) followed by soil volumetric water content (averaged across $0-10 \mathrm{~cm}$ depth; $F=3.55, \quad P=0.00053$; Fig. $1 \mathrm{~b}$ ) and soil temperature (averaged between 2 and $10 \mathrm{~cm}$ depth; $F=2.69$, $P=0.016$; Fig. 1c). The adjusted $R^{2}$ for the nonlinear model was 0.38 , with $48.2 \%$ of deviance explained. Inorganic soil $\mathrm{N}$ content $\left(\mathrm{NH}_{4}\right.$ and $\left.\mathrm{NO}_{3}\right)$ was a weak predictor of flux $\left(\mathrm{NH}_{4}: F=3.04\right.$, $\left.P=0.043 ; \mathrm{NO}_{3}: F=2.28, P=0.061\right)$. 

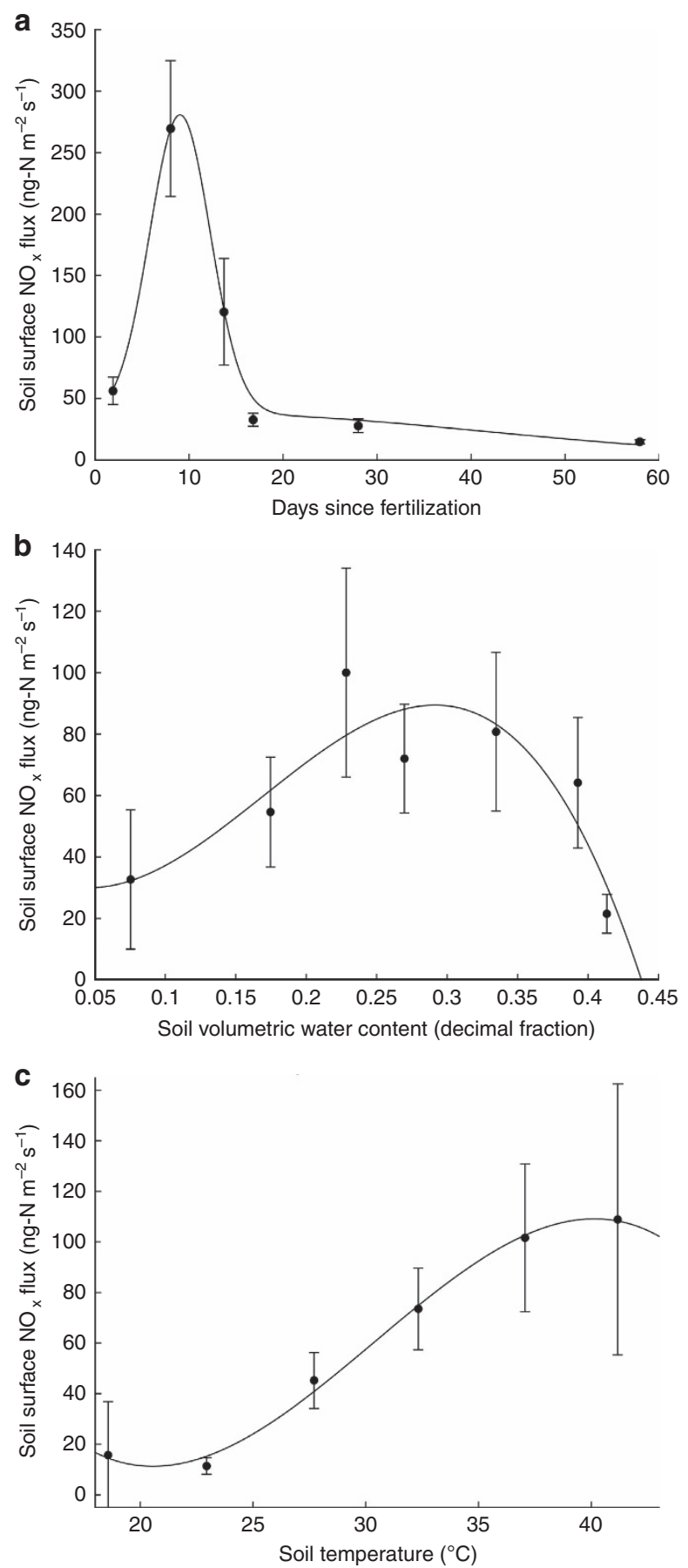

Figure 1 | Environmental variables that regulate soil $\mathrm{NO}_{\mathrm{x}}$ emission. Relationship between soil surface $\mathrm{NO}_{x}$ flux $\left(\mathrm{ng} \mathrm{N} \mathrm{m}^{-2} \mathrm{~s}^{-1}\right.$ ) and (a) days since fertilization, (b) soil volumetric water content $(0-10 \mathrm{~cm})$ and $(\mathbf{c})$ soil temperature (average 2 and $10 \mathrm{~cm} ;{ }^{\circ} \mathrm{C}$ ). Measurements were collected across two growing seasons 2012-2013, including measurements made during fertilization experiments $(n=241)$. Data were binned by environmental variable and s.e. bars are shown for each bin. A Gaussian equation $\left(f(x)=a+b^{*} \exp \left(-0.5((x-c) / d)^{2}\right)\right)$ was fitted to the $\mathrm{NO}_{x}$ relationship with days since fertilization data $(a=18.6, b=254.3, c=8.6$ and $d=3.4)$. A third-order polynomial $\left(f(x)=a^{\star} x^{3}+b^{\star} x^{2}+c^{\star} x+d\right)$ was fitted to the $\mathrm{NO}_{x}$ relationship with soil volumetric water content ( $a=-8128.3, b=4125.5, c=-333.3$ and $d=37.4$ ) and soil temperature $(a=-0.026, b=2.4, c=-64.6$ and $d=562.5)$.
Soil $\mathrm{NO}_{\mathrm{x}}$ emission responses to fertilization and irrigation. In the first $\mathrm{N}$-fertilization experiment, experimental collars received an irrigation and fertilizer treatment $\left(20 \mathrm{~kg} \mathrm{Nha}^{-1}\right.$ dissolved ammonium nitrate) and control collars received irrigation only. During the experiment, soil temperatures at $2 \mathrm{~cm}$ depth were on average $30.0^{\circ} \mathrm{C}\left(\mathrm{s} . \mathrm{d} .=4.5^{\circ} \mathrm{C}\right)$, and plant canopy height was on average $152.3 \mathrm{~cm}$ (15.8 s.d.). N-fertilization treatment and time had a significant effect on $\mathrm{NO}_{\mathrm{x}}$ emissions $(F=30.56, P<0.0001$; $F=12.13, P<0.0001$ for treatment and time effects, respectively). Pairwise comparisons indicated that the fertilized collars were significantly different from control collars 7 days post treatment (Fig. 2a; $P<0.01$ ); all other time points were not significantly different from each other. Numerical integration via the trapezoidal method revealed that treatment collars released $0.13 \mathrm{~g}$ $\mathrm{N}-\mathrm{NO}_{\mathrm{x}} \mathrm{m}^{-2}$ on average during the experiment, corresponding to a $6.6 \%$ emission factor. Control collars released $0.012 \mathrm{~g}$ $\mathrm{N}-\mathrm{NO}_{\mathrm{x}} \mathrm{m}^{-2}$ during the experiment.

To evaluate the importance of rewetting events for $\mathrm{NO}_{\mathrm{x}}$ emissions without a recent fertilization, we conducted a separate analysis of the above experiment, but only included control collars. These control collars received irrigation only and had not been fertilized for over 30 days. In this separate analysis, $\mathrm{NO}_{\mathrm{x}}$ fluxes from control collars were significantly affected by time in response to irrigation (Fig. $2 \mathrm{~b} ; F=4.01, P<0.01$ ), where the third measurement ( 7 days post treatment) was significantly different from all previous measurements $(P<0.05)$, but not the fourth measurement (14 days post treatment; Fig. $2 b$ ), indicating that pulse soil $\mathrm{NO}_{\mathrm{x}}$ emission responses to irrigation occur even over 30 days after fertilization.

In the second $\mathrm{N}$-fertilization experiment, experimental collars received low $\left(50 \mathrm{~kg} \mathrm{Nha}^{-1}\right)$ or high $\left(100 \mathrm{~kg} \mathrm{Nha}^{-1}\right)$ fertilizer treatment plus irrigation, while control collars received irrigation only. Fertilizer was applied via a side injection with urea granules. During the experiment, soil temperatures at $2 \mathrm{~cm}$ depth were on average $37.7^{\circ} \mathrm{C}\left(\right.$ s.d. $\left.=4.2{ }^{\circ} \mathrm{C}\right)$, and plant canopy height was on average $57.8 \mathrm{~cm}$ ( 22.7 s.d.). $\mathrm{N}$-fertilization treatment and time had a significant effect on $\mathrm{NO}_{\mathrm{x}}$ emissions $(F=32.20, P<0.0001$, $F=36.88, P<0.0001$ for treatment and time effects, respectively). Pairwise comparisons indicated that the high-fertilizer treatment collars were significantly different from low-fertilizer treatment and control collars 9 days post treatment (Fig. 3; $P<0.05$ ); no differences between treatments were detected at other time points. Numerical integration via the trapezoidal method revealed

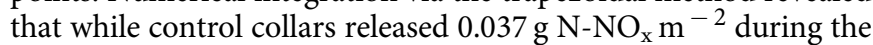
experiment, high-fertilizer treatment collars released $0.46 \mathrm{~g}$ $\mathrm{N}-\mathrm{NO}_{\mathrm{x}} \mathrm{m}^{-2}$ on average during the experiment, corresponding to a $4.6 \%$ emission factor, and low-fertilizer treatment collars released $0.089 \mathrm{~g} \mathrm{~N}-\mathrm{NO}_{\mathrm{x}} \mathrm{m}^{-2}$, corresponding to a $1.8 \%$ emission factor. Therefore, doubling the fertilization amount $\left(50-100 \mathrm{~kg} \mathrm{Nha}^{-1}\right)$ increased integrated fluxes by a factor of 5 .

Investigating the regional significance of soil $\mathrm{NO}_{\mathrm{x}}$ emission. To assess the influence of soil $\mathrm{NO}_{\mathrm{x}}$ emissions on regional air quality, we employed a regional air chemistry model, WRF-Chem, and local and remotely sensed measurements of $\mathrm{NO}_{2}$ in the troposphere. We then increased soil $\mathrm{NO}_{\mathrm{x}}$ emission rates within the model to reach levels similar to those measured in the field and compared the modelled $\mathrm{NO}_{2}$ (default and elevated simulations) with measured surface $\mathrm{NO}_{2}$ concentrations and tropospheric $\mathrm{NO}_{2}$ columns. Finally, we evaluated the effect of increasing soil $\mathrm{NO}_{\mathrm{x}}$ emissions on modelled tropospheric $\mathrm{O}_{3}$.

First, we compared soil $\mathrm{NO}_{\mathrm{x}}$ emissions modelled in WRF-Chem with emissions measured in the field. By default, WRF-Chem estimated surface $\mathrm{NO}_{\mathrm{x}}$ emissions in the Imperial Valley to be near $2 \mathrm{ng} \mathrm{NO}_{\mathrm{x}}-\mathrm{Nm}^{-2} \mathrm{~s}^{-1}$. Across 

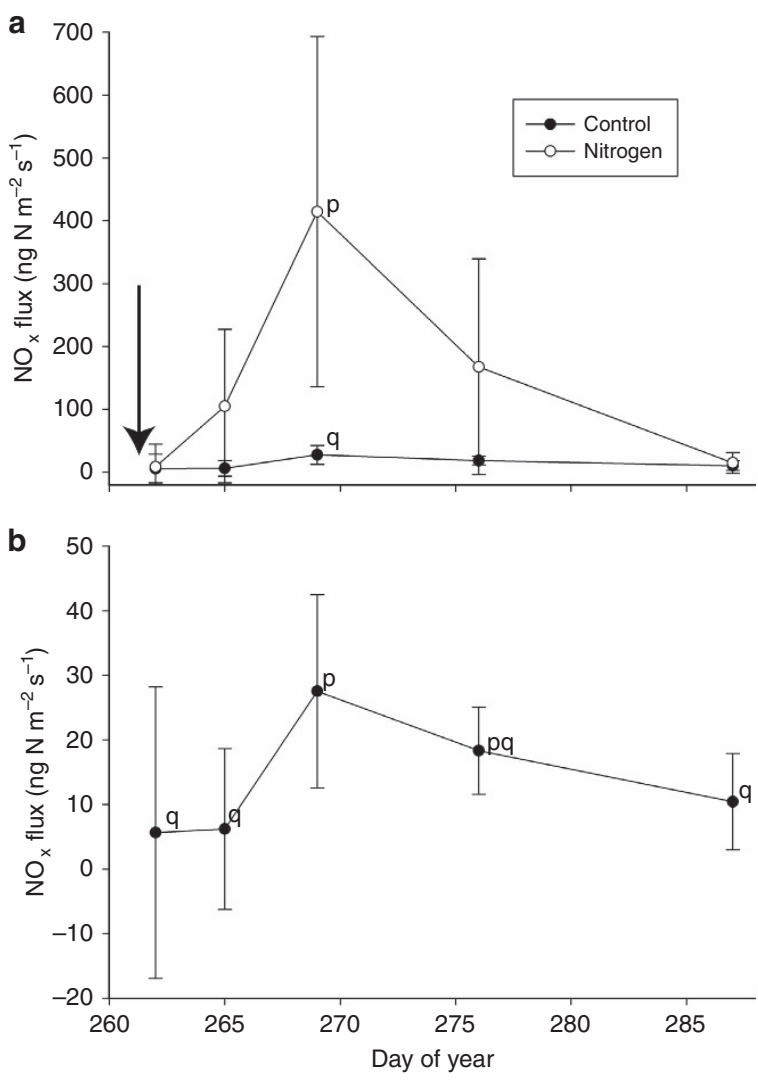

Figure 2 | Pulse $\mathrm{NO}_{\mathrm{x}}$ emission responses to dissolved ammonium nitrate fertilization. (a) Soil $\mathrm{NO}_{x}$ fluxes observed during a $\mathrm{N}$-fertilization experiment in 2012 where collars received $20 \mathrm{~kg}$ ammonium nitrate- $\mathrm{N} \mathrm{ha}^{-1}$ in dissolved form during an irrigation (white circles; $n=10$ ) and control collars received irrigation only (black circles; $n=10$; s.d. bars shown). The irrigation and fertilization event is indicated by an arrow (DOY 262). $\mathrm{N}$ treatment significantly increased $\mathrm{NO}_{x}$ emissions with peak emissions observed 7 days post fertilization. (b) Control collar $\mathrm{NO}_{x}$ fluxes were also evaluated in a separate analysis to investigate the influence of irrigation alone on $\mathrm{NO}_{x}$ flux. Control $\mathrm{NO}_{x}$ fluxes were significantly affected by time during the experiment in response to irrigation, where fluxes observed during the third measurement ( 7 days post treatment) were significantly different from all other measurements except for the fourth measurement (14 days post treatment). Significant differences between time points are indicated by letters $(p, q)$ at $P<0.05$, as determined using pairwise comparisons with Bonferroni adjustment.

all our measurements, $\mathrm{NO}_{\mathrm{x}}$ fluxes were on average $66.4 \mathrm{ng}$ $\mathrm{NO}_{\mathrm{x}}-\mathrm{Nm}^{-2} \mathrm{~s}^{-1}$ with a median of $20 \mathrm{ng} \mathrm{NO}_{\mathrm{x}}-\mathrm{Nm}^{-2} \mathrm{~s}^{-1}$. Across measurements made within 20 days of a fertilization event, $\mathrm{NO}_{\mathrm{x}}$ fluxes were on average $128.1 \mathrm{ng} \mathrm{NO}_{\mathrm{x}}-\mathrm{Nm}^{-2} \mathrm{~s}^{-1}$ with a median of $38 \mathrm{ng} \mathrm{NO}_{\mathrm{x}}-\mathrm{Nm}^{-2} \mathrm{~s}-1$. By multiplying WRF-Chem emission rates by factors of 10 and 64.5, we elevated soil $\mathrm{NO}_{\mathrm{x}}$ emissions in Imperial Valley croplands to be near 20 and $129 \mathrm{ng} \mathrm{NO} \mathrm{N}_{\mathrm{x}}-\mathrm{N} \mathrm{m}^{-2} \mathrm{~s}^{-1}$, which are representative of the range in mean and median flux values collected under both average and recently fertilized conditions in the field.

We then compared modelled surface $\mathrm{NO}_{2}$ concentrations in the Imperial Valley with surface $\mathrm{NO}_{2}$ measurements collected at an air quality monitoring site (CA Air Resources Board, El Centro-9th Street, CA; Fig. 4). Meteorological conditions were stable, with no rainfall and consistent temperature and radiation during the simulation period (average air temperature $=30.29^{\circ} \mathrm{C}$, s.d. = 1.9; average daily net radiation $=110.9 \mathrm{~W} \mathrm{~m}^{-2}$, s.d. $=4.1$ ). WRF-Chem default parameterization performed well, especially

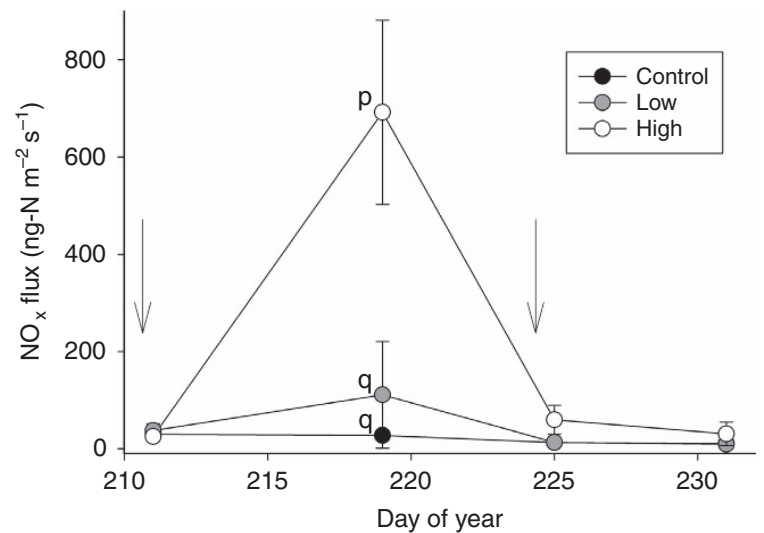

Figure 3 | Pulse $\mathrm{NO}_{\mathbf{x}}$ emission responses to side-injected urea fertilization. Soil $\mathrm{NO}_{x}$ fluxes observed during a fertilization experiment in 2013 with control $(\mathrm{ON})$, low $\left(50 \mathrm{~kg}\right.$ urea-N ha${ }^{-1}$ ) and high (100 kg urea$\mathrm{Nha}^{-1}$ ) side-injected fertilization treatments ( $n=3$ collars per treatment; s.d. bars shown). Irrigation events are indicated by arrows. Fertilization occurred on DOY 210. High-fertilizer treatment collars were significantly different from low-fertilizer treatment and control collars at the second time point ( 9 days post treatment); no differences between treatments were detected at other time points. Significant differences between time points are indicated by letters $(p, q)$ at $P<0.05$, as determined using pairwise comparisons with Bonferroni adjustment.

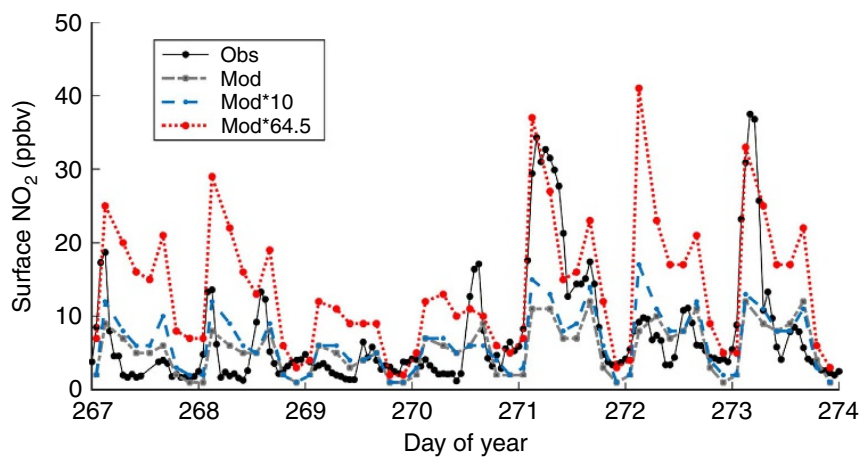

Figure 4 | Comparing time series of modelled and measured surface concentrations of $\mathbf{N O}_{\mathbf{2}}$ in the Imperial Valley, CA. Surface concentrations of $\mathrm{NO}_{2}$ measured at an air quality monitoring station (obs) in El Centro, CA (CA Air Resources Board) and modelled with WRF-Chem (mod) and WRF-Chem with soil $\mathrm{NO}_{2}$ emission rates multiplied by $10\left(\bmod ^{\star} 10\right)$ and $64.5 \times\left(\bmod ^{\star} 64.5\right)$. All data are from 23 to 29 September 2012.

on days when $\mathrm{NO}_{2}$ surface concentrations were low (for example, day of year (DOY) 269; Fig. 4) and tended to underestimate peak $\mathrm{NO}_{2}$ concentrations early in the morning when the daytime boundary layer was developing and pollutants, including $\mathrm{NO}_{2}$, were not well mixed (for example, DOY 271; Fig. 4; Supplementary Fig. 1). All model simulations explained significant amounts of variation in observed surface $\mathrm{NO}_{2}$ during the simulation period (Fig. 5), with the least amount of bias occurring when soil $\mathrm{NO}_{\mathrm{x}}$ emissions in the model were increased by an order of magnitude (root mean s.e. (r.m.s.e.) =6.1, 5.7 9.5 p.p.b.v. for model default, model $^{\star} 10 \operatorname{model}^{\star} 64.5$, respectively). These results suggest that an improved soil $\mathrm{NO}_{\mathrm{x}}$ emission factor in WRF-Chem would be close to 10 or $20 \times$ higher than default to match observed surface concentrations of $\mathrm{NO}_{2}$ in the Imperial Valley. When soil $\mathrm{NO}_{\mathrm{x}}$ emissions were increased $64.5 \times$, the model overestimated surface $\mathrm{NO}_{2}$ by $81 \%$ across the simulation period. 


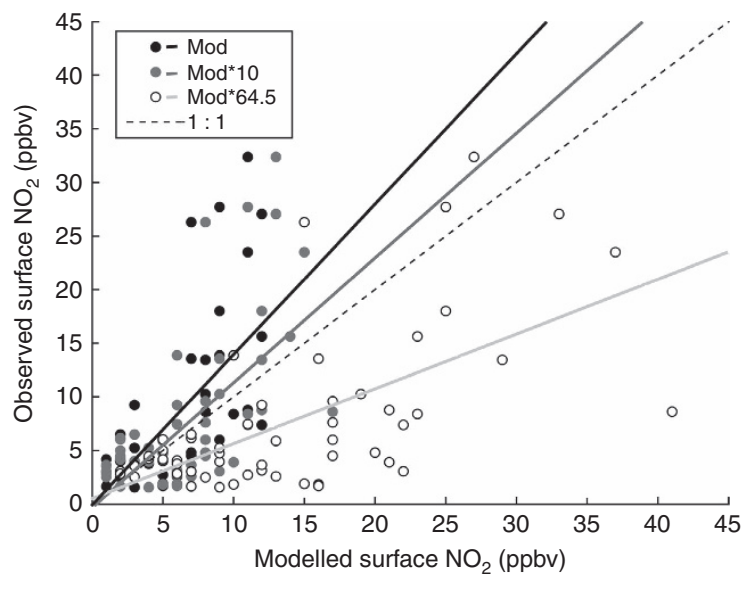

Figure 5 | Comparing modelled and measured surface $\mathrm{NO}_{2}$ concentrations in El Centro, CA. Surface concentrations of $\mathrm{NO}_{2}$ (p.p.b.v.) at an air quality monitoring station in El Centro, CA (CA Air Resources Board; obs) and modelled with WRF-Chem (mod) and WRF-Chem with soil $\mathrm{NO}_{2}$ emission rates multiplied by $10\left(\bmod ^{\star} 10\right)$ and $64.5\left(\bmod ^{\star} 64.5\right)$. All data are from 23 to 29 September 2012. The dashed line represents the 1:1 relationship; all other lines correspond to linear regressions between modelled and observed data (default model $r^{2}=0.44$, slope $=1.4$, intercept $=0.14 ; \bmod ^{\star} 10 r^{2}=0.44$, slope $=1.1$, intercept $=0.38 ; \bmod ^{\star} 64.5$ $r^{2}=0.42$, slope $=0.5$, intercept $=0.7$ ). All linear regressions were significant at $P<0.0001$.

An additional analysis was conducted using only data at local time 13:00-16:00 when the boundary layer was well developed at an average of $1,587 \mathrm{~m}$ (s.d. $=796 \mathrm{~m}$; Supplementary Fig. 1) and overlapping with Ozone-monitoring instrument (OMI) overpass time (12:00-13:30). However, the results were similar to the analysis including all data (Fig. 5) and therefore are not shown.

While the discrepancies between measured and modelled surface $\mathrm{NO}_{2}$ concentrations may be due to the model underestimating soil $\mathrm{NO}_{\mathrm{x}}$ emissions from local agricultural fields, they may also be due to mischaracterized local meteorology or underestimated $\mathrm{NO}_{\mathrm{x}}$ emissions inventories from local biomass burning and/or fossil fuel combustion. To investigate alternative sources of error, we first compared locally measured meteorological variables with simulated meteorological variables and found high agreement between modelled and measured air temperature and wind speed during the simulation period $\left(r^{2}=0.60\right.$, r.m.s.e. $=2.3^{\circ} \mathrm{C}$ and $r^{2}=0.80$, r.m.s.e. $=0.58 \mathrm{~m} \mathrm{~s}^{-1}$ for air temperature and daily average wind speed, respectively). We also examined the infrared anomaly (fire) data from MODIS and determined that no large biomass burning events had occurred during 20-29 September 2012. The discrepancies between modelled and measured $\mathrm{NO}_{2}$ may also be due to under-represented fossil fuel combustion rates; however, the fossil fuel combustion $\mathrm{NO}_{\mathrm{x}}$ emission data used in the model are known to overestimate anthropogenic $\mathrm{NO}_{\mathrm{x}}$ sources by $32 \%$ in southern California $^{30}$.

We also compared remotely sensed measurements of tropospheric $\mathrm{NO}_{2}$ columns with WRF-Chem model simulations. The OMI satellite-derived tropospheric $\mathrm{NO}_{2}$ columns suggest that WRF-Chem underestimates $\mathrm{NO}_{2}$ above the Imperial Valley by $63 \%$ during the simulation period $\left(0.75\right.$ and $2.05^{\star} 10^{19}$ molecules $\mathrm{NO}_{2} \mathrm{~m}^{-2}$ for WRF-Chem and OMI, respectively; Fig. 6a,c). Elevating soil $\mathrm{NO}_{\mathrm{x}}$ emissions by an order of magnitude still resulted in the model underestimating observed tropospheric $\mathrm{NO}_{2}$ columns by $56 \%\left(0.90^{*} 10^{19}\right.$ molecules $\mathrm{NO}_{2}$ per $\mathrm{m}^{2}$ above the Imperial Valley). However, elevating soil $\mathrm{NO}_{\mathrm{x}}$ emissions by
$64.5 \times$ led to good agreement with observed tropospheric $\mathrm{NO}_{2}$ columns $\left(2.0^{*} 10^{19}\right.$ molecules $\mathrm{NO}_{2}$ per $\mathrm{m}^{2}$ above the Imperial Valley; Fig. 6e,g).

WRF-Chem simulations with elevated soil $\mathrm{NO}_{\mathrm{x}}$ emission rates resulted in significant increases in surface $\mathrm{O}_{3}$ concentration. Under default conditions, WRF-Chem estimates $\mathrm{O}_{3}$ at 41.5 p.p.b.v. in the Imperial Valley across 3 days in September 2012 (Fig. 6d). Increasing soil $\mathrm{NO}_{\mathrm{x}}$ emissions by 10 and $64.5 \times$ increased $\mathrm{O}_{3}$ levels by 2.2 and 8.5 p.p.b.v., respectively (Fig. 6f,h). These modelled $\mathrm{O}_{3}$ concentrations highlight the sensitivity of air quality to soil $\mathrm{NO}_{\mathrm{x}}$ emissions in the region and confirm that this air shed is $\mathrm{NO}_{\mathrm{x}}$ limited.

\section{Discussion}

We find that $\mathrm{NO}_{\mathrm{x}}$ emission rates from high-temperature agricultural soils in the Imperial Valley are some of the highest ever reported ${ }^{8,31}$. Despite differences in fertilizer type and application method, both fertilization experiments resulted in higher than expected $\mathrm{NO}_{\mathrm{x}}$ fluxes with emission factors ranging between 1.8 and $6.6 \%$ over the course of 20-25 days following treatment. Our approximated emission factors are likely an underestimation, as they were derived from non-continuous short monitoring periods highlighting the need for continuous flux measurements. Overall, our results suggest that commonly applied $\mathrm{NO}_{\mathrm{x}}$ emission factors (typically 1-2\% across an entire growing season ${ }^{5,8,23}$ ) are highly uncertain and underestimate $\mathrm{NO}_{\mathrm{x}}$ emissions in high-temperature agricultural systems.

We also find that $\mathrm{NO}_{\mathrm{x}}$ emissions are best predicted through nonlinear relationships with time since fertilization, soil temperature and soil moisture. Incorporating nonlinear $\mathrm{NO}_{\mathrm{x}}$ emission responses to these factors into biogeochemical models is becoming more common. In particular, Hudman et al. ${ }^{9}$ account for pulse emission responses to fertilization and continuous dependence on soil moisture (instead of distinct wet/dry states) within the Berkeley-Dalhousie Soil $\mathrm{NO}_{\mathrm{x}}$ Parameterization model, which is available in GEOS-Chem, a global chemistry transport model. However, many models (including the Berkeley-Dalhousie Soil $\mathrm{NO}_{\mathrm{x}}$ Parameterization model) do not account for $\mathrm{NO}_{\mathrm{x}}$ emission responses to different levels, chemical species, application methods of fertilization, irrigation events in agricultural systems and nonlinear $\mathrm{NO}_{\mathrm{x}}$ emission responses to high temperature $\left(>30^{\circ} \mathrm{C}\right)$. Our study highlights these factors as critical functions influencing $\mathrm{NO}_{\mathrm{x}}$ emissions.

Fertilization management, including the type of fertilizer used and how it is applied, is critical for minimizing the loss of $\mathrm{N}$ to the atmosphere in the form of $\mathrm{NO}_{\mathrm{x}}$. Our fertilization experiment revealed strong nonlinear increases in flux response to increases in fertilizer amount. This extends previous work suggesting that large fertilization events result in higher than expected $\mathrm{NO}_{\mathrm{x}}$ emissions and splitting fertilization into smaller amounts can greatly reduce $\mathrm{NO}_{\mathrm{x}}$ emissions ${ }^{5}$. Our experiments also demonstrate that using side-injected granular urea- $\mathrm{N}$-fertilizer results in lower $\mathrm{NO}_{\mathrm{x}}$ emissions than a dissolved $\mathrm{NH}_{4} \mathrm{NO}_{3}-\mathrm{N}$ application. Application of $50 \mathrm{~kg}$ urea- $\mathrm{Nha}^{-1}$ induced an integrated flux that was $30 \%$ lower than a $20-\mathrm{kg} \mathrm{NH}_{4} \mathrm{NO}_{3}-$ $\mathrm{N} \mathrm{ha}^{-1}$ treatment. Urea is a more complex $\mathrm{N}$ source requiring an extra step before it can serve as a substrate in nitrification and denitrification, while ammonium nitrate is a direct substrate for both nitrification and denitrification. This supports previous research conducted in lower-temperature environments, suggesting that side injection and complex $\mathrm{N}$ (for example, urea) limit $\mathrm{N}$ trace gas emissions ${ }^{5,32}$. Fertilizer management is therefore a critical factor for minimizing $\mathrm{N}$ losses to the atmosphere and reducing adverse effects to air quality in hightemperature agroecosystems. 


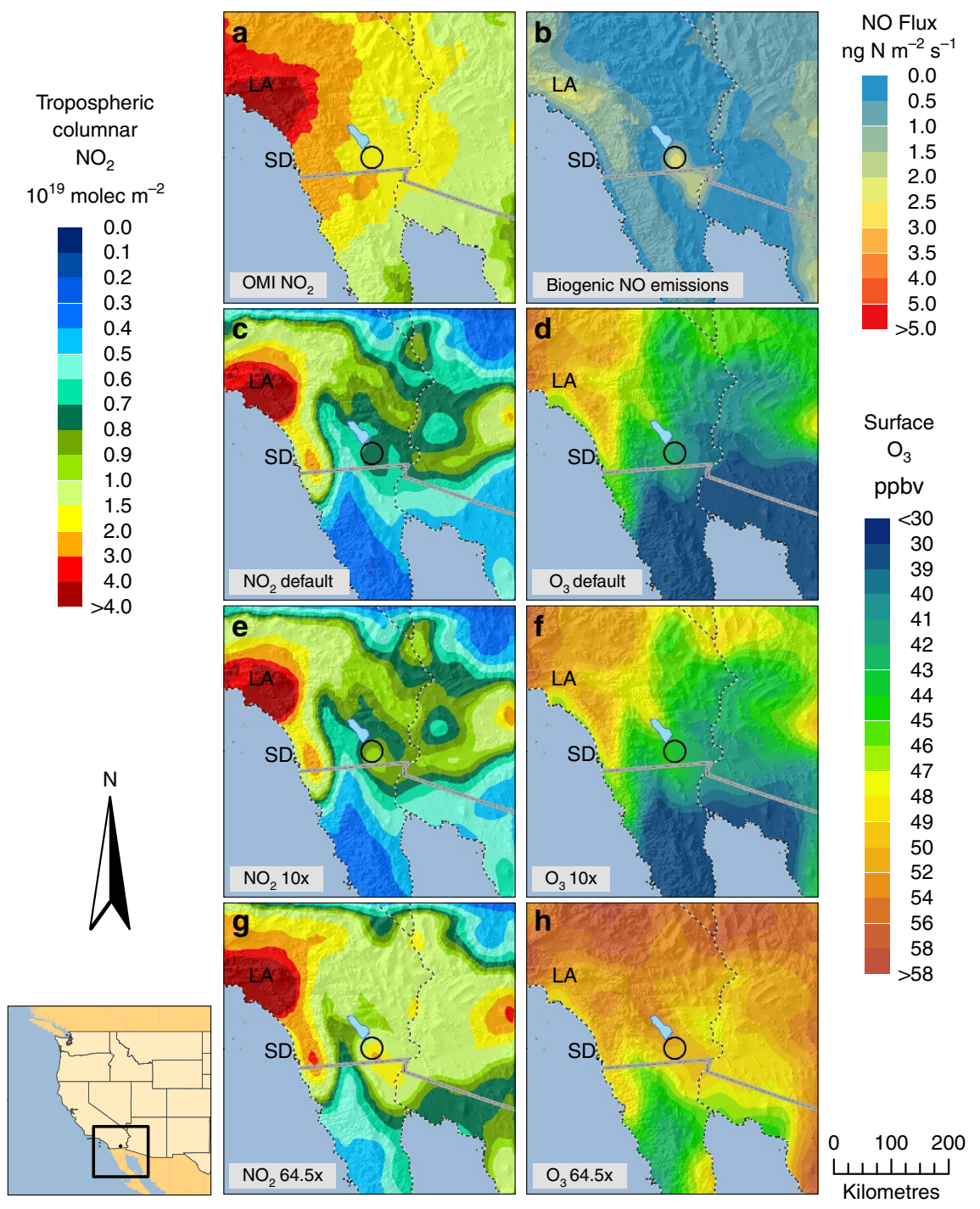

Figure 6 | $\mathbf{N O}_{\mathbf{2}}$ and $\mathbf{O}_{\mathbf{3}}$ distributions from WRF-Chem and $\mathbf{O M I}$ above the Imperial Valley. Distribution of tropospheric columnar $\mathrm{NO}_{2}$ retrieved by

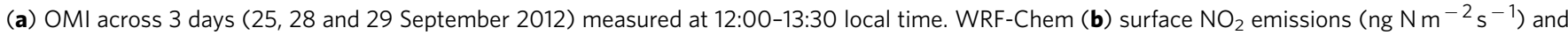
(c) tropospheric $\mathrm{NO}_{2}$ columns are also shown across the same 3 days at 12:00-13:30 local time. Soil $\mathrm{NO}_{2}$ emission rates from cropland were elevated within WRF-Chem (e) $10 \times$ and (g) $64.5 \times$ above default resulting in higher tropospheric $\mathrm{NO}_{2}$ columns. WRF-Chem simulations of surface $\mathrm{O}_{3}$ concentrations (p.p.b.v.) are also shown corresponding to the (d) default, (f) $10 \times$ and (h) $64.5 \times$ elevated soil $\mathrm{NO}_{2}$ emission runs. All tropospheric $\mathrm{NO}_{2}$ column units are in $10^{19}$ molecules $\mathrm{NO}_{2}$ per $\mathrm{m}^{2}$. The Imperial Valley study region is circled in black in each panel. Nearby cities are also indicated within each panel as San Diego (SD) and Los Angeles (LA).

We find $\mathrm{NO}_{\mathrm{x}}$ emission pulses in response to irrigation alone, a response consistent with a previously described hypothesis that fertilized soil will continue to exhibit pulse $\mathrm{NO}_{\mathrm{x}}$ emission behaviour with multiple irrigation events ${ }^{2}$. Long-term effects of fertilization on soil $\mathrm{NO}_{\mathrm{x}}$ production may therefore significantly contribute to annual $\mathrm{NO}_{\mathrm{x}}$ budgets. Models often assume agricultural systems maintain constant soil-moisture conditions $^{33}$; however, soil surface drying between irrigation events is common in high-temperature arid agroecosystems ${ }^{34}$. Our results stress the importance of understanding how combined fertilization and irrigation practices influence soil $\mathrm{NO}_{\mathrm{x}}$ emissions.

Soil $\mathrm{NO}_{\mathrm{x}}$ models often assume $\mathrm{NO}_{\mathrm{x}}$ emission exponentially increases with temperature until a plateau is reached above $30^{\circ} \mathrm{C}$ (ref. 9). Our results highlight nonlinear responses in $\mathrm{NO}_{\mathrm{x}}$ emissions above $30^{\circ} \mathrm{C}$, where soil $\mathrm{NO}_{\mathrm{x}}$ emissions increase $38 \%$ on average as soil temperatures increase from $30-35$ to $35-40{ }^{\circ} \mathrm{C}$
(Fig. 1). While exponential relationships between soil temperature and soil $\mathrm{NO}_{\mathrm{x}}$ emissions are valuable for predicting flux, these responses need to be parameterized to different environmental conditions. This is especially true in high-temperature environments such as the Imperial Valley where microbial acclimation to high temperature and/or increased contributions of deeper and cooler soil layers $(>10 \mathrm{~cm})$ to surface $\mathrm{NO}_{\mathrm{x}}$ emissions may be significant. While we did not observe inhibition of $\mathrm{NO}_{\mathrm{x}}$ emissions above $35^{\circ} \mathrm{C}$, higher temperatures than those covered in this study $\left(>40^{\circ} \mathrm{C}\right)$ may reveal inhibition of $\mathrm{NO}_{\mathrm{x}}$ emissions.

We find evidence that the regional air chemistry model WRF-Chem underestimates soil $\mathrm{NO}_{\mathrm{x}}$ emissions, tropospheric $\mathrm{NO}_{2}$ columns and, at times, surface $\mathrm{NO}_{2}$ concentrations in the Imperial Valley. Default WRF-Chem simulation of soil $\mathrm{NO}_{\mathrm{x}}$ emissions from agricultural land was on average $2.0 \mathrm{ng} \mathrm{N} \mathrm{m}{ }^{-2} \mathrm{~s}^{-1}$ (Fig. 6b), much lower than observed in the Sorghum field (on average $65 \mathrm{ng} \mathrm{N} \mathrm{m}^{-2} \mathrm{~s}^{-1}$ across all 
measurements). Model simulations of tropospheric $\mathrm{NO}_{2}$ columns also underestimated observed values. These results agree with previous research showing that satellite-derived (OMI) tropospheric $\mathrm{NO}_{2}$ columns are elevated above agricultural land in the Western United States of America, and that these sources are underestimated in current models ${ }^{23}$. However, the model did not consistently underestimate surface $\mathrm{NO}_{2}$ (for example, DOY 272; Fig. 4). While increasing soil $\mathrm{NO}_{\mathrm{x}}$ emission rates by $64.5 \times$ within WRF-Chem led to strong overestimation of surface $\mathrm{NO}_{2}$ observations, it led to good agreement with tropospheric $\mathrm{NO}_{2}$ column observations. Our results therefore indicate that there is no single emission factor that can be used to accurately simulate both tropospheric $\mathrm{NO}_{2}$ columns and $\mathrm{NO}_{2}$ observed at the surface. On the basis of field measurements, soil $\mathrm{NO}_{\mathrm{x}}$ emissions are highly variable depending on fertilization, soil temperature and soil moisture. We therefore advocate for modifying model structure within WRF-Chem to incorporate these $\mathrm{NO}_{\mathrm{x}}$ emission dynamics, versus simply increasing emission factors. This is an important area for future research.

High soil $\mathrm{NO}_{\mathrm{x}}$ emissions are likely contributing to high concentrations of tropospheric $\mathrm{O}_{3}$ in the Imperial Valley. Elevating soil $\mathrm{NO}_{\mathrm{x}}$ emission rates within the model to the point where better agreement was achieved with observations led to significantly higher concentrations of simulated surface $\mathrm{O}_{3}$. These model simulations suggest that air chemistry in the region is $\mathrm{NO}_{\mathrm{x}}$ limited and therefore sensitive to soil $\mathrm{NO}_{\mathrm{x}}$ emissions. Intensive agriculture in the Imperial Valley and associated high soil $\mathrm{NO}_{\mathrm{x}}$ emissions may therefore be contributing to poor air quality in the region. Soil $\mathrm{NO}_{\mathrm{x}}$ emissions may also be contributing to the formation of particulate nitrate, another threat to human respiratory health. The management of fertilizers may be a valuable approach for reducing the negative impacts of agriculture on human health in the Imperial Valley.

There are multiple factors that could lead to WRF-Chem underestimating tropospheric $\mathrm{NO}_{2}$ columns and, at times, surface $\mathrm{NO}_{2}$ concentrations in the Imperial Valley. While we investigated some of these factors (for example, poorly constrained soil $\mathrm{NO}_{\mathrm{x}}$ emissions, meteorology and biomass burning $\mathrm{NO}_{2}$ sources), more intensive evaluation and improved model parameterization will be required to advance predictive skill of $\mathrm{NO}_{2}$ and $\mathrm{O}_{3}$ dynamics in the region. First, to improve regional scale modelling of agricultural $\mathrm{NO}_{\mathrm{x}}$ emissions, future studies require $\mathrm{NO}_{\mathrm{x}}$ flux measurements across all dominant crop types in the Imperial Valley paired with spatially explicit management data, including irrigation and fertilization practices. Second, improved model structure informed by relationships presented in Fig. 1 will be required for predicting soil $\mathrm{NO}_{\mathrm{x}}$ emission responses to temperature, irrigation and fertilization. Third, biogenic volatile organic compound emissions in high-temperature irrigated environments $^{35}$ and fossil fuel combustion inventories need to be better constrained to more accurately evaluate the significance of soil $\mathrm{NO}_{\mathrm{x}}$ sources for tropospheric $\mathrm{O}_{3}$ production. This is particularly important as previous work has shown that the EPA's NEI-05 emission data significantly overestimate anthropogenic $\mathrm{NO}_{\mathrm{x}}$ sources in Southern California ${ }^{30}$. Improving WRF-Chem performance will therefore require evaluation of both model structure and model input data with regard to multiple sources of agricultural and anthropogenic organic compounds and $\mathrm{NO}_{\mathrm{x}}$ in the Imperial Valley.

In summary, we find high $\mathrm{N}$ losses in the form of $\mathrm{NO}_{\mathrm{x}}$ from high-temperature agroecosystems that are not well represented by a current air chemistry model. Managing soil $\mathrm{NO}_{\mathrm{x}}$ emissions should be considered in future efforts to improve regional air quality in the Imperial Valley, a region that regularly exceeds government $\mathrm{O}_{3}$ standards ${ }^{14}$ and suffers from the highest rates of asthma hospitalizations in California ${ }^{15}$. Our results suggest that smaller doses of side-injected dry fertilizers with complex $\mathrm{N}$ formulations may help reduce $\mathrm{NO}_{\mathrm{x}}$ emissions and thereby increase nutrient-use efficiency. There is growing concern over the sustainability of agricultural production in regions of the world that have been experiencing higher temperatures and more frequent heat waves ${ }^{1}$. Results from this study highlight the need for improved understanding of fertilized high-temperature environments, for better representation in air chemistry transport models and for development of sustainable management of agricultural land in a future warmer climate.

\section{Methods}

Study location and experimental design. All measurements were conducted in experimental agricultural fields located in the low elevation ( $-18 \mathrm{~m} \mathrm{ASL})$ University of California Desert Research and Extension Center (DREC), Holtville, Imperial County, CA $\left(32^{\circ} \mathrm{N} 48^{\prime} 42.6^{\prime \prime}, 115^{\circ} \mathrm{W} 26^{\prime} 37.5^{\prime \prime}\right)$ characterized by deep alluvial soils ( $42 \%$ clay, $41 \%$ silt and $16 \%$ sand) with $2.34 \% \mathrm{C}$ and $0.13 \% \mathrm{~N}$, and a $\mathrm{pH}$ of 8.3. The field site experienced historically typical air temperatures during the experiments conducted in 2012 and 2013 (ref. 36). Two N-fertilization studies were conducted under cultivation of a forage cultivar of S. bicolor (cv. Photoperiod LS; Scott Seed Inc.) in adjacent fields. Seed of S. bicolor were planted at 90,000 plants per ha. High-biomass-producing grasses including sorghum, sudangrass and sugarcane are the 4th most common crop type in the Imperial Valley, behind Alfalfa, pasture and vegetables ${ }^{37}$. These high-biomass-producing grasses typically receive a large fertilizer application at planting $\left(100-150 \mathrm{~kg} \mathrm{~N} \mathrm{ha}^{-1}\right)$ followed by smaller applications $\left(50 \mathrm{~kg} \mathrm{Nha}^{-1}\right)$ throughout the growing season, typically following harvests ${ }^{38,39}$. Fertilizers are often applied by injecting anhydrous fertilizer into the sides of furrows or by broadcasting fertilizer on the soil surface. The cheapest form of fertilizer is dry urea, but ammonium nitrate and ammonia are also used ${ }^{40}$. The fields were gravity-fed flood irrigated as needed, usually every 10 days or when soil surface volumetric water content fell below $0.10 \mathrm{~cm}^{3} \mathrm{~cm}^{-3}$ Gravity-fed flood irrigation is the most prevalent irrigation practice in the Imperial Valley; $70 \%$ of irrigated crops using water from the Colorado River use flood irrigation $^{41}$. Both fields had beds separated by $1.5 \mathrm{~m}$ with 20 -cm-deep furrows, and have been used for agricultural production at least since the establishment of DREC in 1912. The first experiment was conducted in a large experimental field (5.3 ha) in 2012 and the second in a smaller field (0.4 ha) in 2013.

Large-field measurements. Seed of S. bicolor were planted on 16 February 2012. Urea fertilizer treatments of $90 \mathrm{~kg} \mathrm{Nha}^{-1}$ were applied with a 3-m-wide fertilizer spreader on 10 February, 18 June and 16 August 2012, totalling to $270 \mathrm{~kg} \mathrm{Nha}^{-1}$ per year. Pesticides were applied at $2.11 \mathrm{ha}^{-1}$ on 30 April 2012 (Lorsban insecticide, Dow AgroSciences, Indiana, USA) and herbicides were applied at $0.84 \mathrm{~kg} \mathrm{ha}^{-1}$ on 27 March 2012 (Maestro, Nufarm Americas Inc., Illinois, USA) Three harvests were conducted in 2012 on 4 June, 14 August and 12 November (corresponding to DOY 156, 227 and 317, respectively). The second and third growth periods were ratoon crops. The field was left fallow in the winter and was re-seeded on 1 April 2013. Sorghum was planted later in the season in 2013 due to late rains. In 2013, only two harvests were conducted on 19 July and 18 September 2013. Fertilizer treatments were applied on 29 May 2013 at $52 \mathrm{~kg} \mathrm{Nha}^{-1}$ (side dressed urea), 20 June at $66 \mathrm{~kg} \mathrm{Nha}^{-1}$ (mixture of urea-ammonium nitrate solution (32\%) and 8\% ammonium nitrate organic solution), and 20 August 2013 as $96 \mathrm{~kg} \mathrm{Nha}^{-1}$ (urea-ammonium nitrate $32 \%$ ), totalling to $214 \mathrm{~kg} \mathrm{~N}$ ha $^{-1}$ per year. No pesticides or herbicides were applied in 2013 .

We installed 20 soil collars on 20 February 2012, split between the northwest and southeast quadrants. In each quadrant, 10 collars were divided between two rows separated by three furrows. Soil $\mathrm{NO}_{\mathrm{x}}$ measurements were conducted throughout the growing season to assess general trends in $\mathrm{NO}_{\mathrm{x}}$ emissions $(21$ March, 22 May, 27 June, 7 August and 20 August corresponding to DOY 81, 143 , 179, 220 and 233, respectively) and again in 2013 (9 July, 30 July, 19 August, 22 August, 28 August and 2 September corresponding to DOY 190, 211, 231, 234, 240 and 245 , respectively). Due to difficulties with instrumentation, not all collars were measured on every sampling occasion.

In the first $\mathrm{N}$-fertilization experiment in 2012, 10 experimental collars received an irrigation and fertilizer treatment (dissolved $20 \mathrm{~kg}$ ammonium nitrate- $\mathrm{N} \mathrm{ha}{ }^{-1}$ ) on 18 September 2012, while 10 control collars received irrigation only (with five collars in the southeast quadrant and five in the northwest quadrant randomly receiving fertilization). Collars were fertilized concurrent with flood irrigation of the entire field. Before the experimental fertilization, the field had not received fertilization for 32 days (at $90 \mathrm{~kg}$ urea-N ha ${ }^{-1}$ ). During this experiment, each collar was measured on 18 September, 21 September, 25 September, 5 October and 13 October (corresponding to DOY 262, 265, 269, 279 and 287, respectively). Plant canopy height next to each collar was also measured on those dates.

Small-field measurements. A similar $\mathrm{N}$-fertilization experiment was conducted in 2013 in an adjacent Sorghum field (planted on 1 April 2014). We installed soil collars on 23 July 2013 in a randomized block design where the field was split into 
three blocks each with six rows of control, six rows of low $\left(50 \mathrm{~kg}\right.$ urea-N ha $\left.{ }^{-1}\right)$ fertilizer treatment and six rows of high $\left(100 \mathrm{~kg}\right.$ urea- $\left.\mathrm{N} \mathrm{ha}^{-1}\right)$ fertilizer treatment. One soil collar was established within each treatment per block (nine soil collars total with three replicates per treatment). Fertilizer granules (urea) were sideinjected into the furrows using a tractor, immediately followed by flood irrigation on 29 July 2013 (DOY 210). Before the experimental fertilization, the crop had not received fertilization. Soils in this field had not been fertilized since the cultivation of a previous crop 5 months before. Measurements were collected on 30 July, 7 August, 13 August and 19 August 2013 (corresponding to DOY 211, 219, 225 and 231, respectively). Plant canopy height next to each collar was also measured on those dates.

Soil $\mathrm{NO}_{\mathrm{x}}$ flux measurements. $\mathrm{NO}_{\mathrm{x}}$ chamber measurements were conducted using the static chamber technique. Soil collars (made of polyvinyl chloride with a diameter of $20 \mathrm{~cm}$ and height of $10 \mathrm{~cm}$ ) were inserted $4-6 \mathrm{~cm}$ into the soil on the top of furrows. A custom-built chamber was set on top of soil collars and set into place using a rubber seal. The chamber was also made from polyvinyl chloride with a mixing fan mounted on the inside and reflective tape covering the outside of the chamber ${ }^{42}$. Air was pulled from the top of the chamber at $11 \mathrm{~min}^{-1}$ and routed to a portable NO monitor (Nitric Oxide Monitor Model 410 with $\mathrm{NO}_{2}$ converter Model 401, 2B Technologies, Colorado, USA) where depletion of $\mathrm{O}_{3}$ is measured using UV absorbance (detection range: 2-2,000 p.p.b.; precision: \pm 1.5 p.p.b.; measurement rate: $0.1 \mathrm{~Hz}$ ). This system converts all $\mathrm{NO}_{2}$ to $\mathrm{NO}$ using a molybdenum converter before sending sample air to the NO monitor, therefore measurements are expressed as $\mathrm{NO}_{\mathrm{x}}$ flux $\left(\mathrm{NO}+\mathrm{NO}_{2}\right)$. This technique is similar to conventional chemiluminescence analyzers; however, we found our system to be better suited to high-emission environments compared with chemiluminescence instruments in preliminary studies conducted in both field and lab settings. Soil $\mathrm{NO}_{\mathrm{x}}$ flux was calculated using the rate of increase in $\mathrm{NO}_{\mathrm{x}}$ concentration within the first $3 \mathrm{~min}$ of placing the chamber onto the collar. We used linear regression to determine rates of change from an average of nine points in the regression or $1.5 \mathrm{~min}$ of data.

Ancillary soil sampling and inorganic soil $\mathbf{N}$ analysis. Each flux measurement was paired with soil temperature, moisture and inorganic $\mathrm{N}$ measurements. Soil temperature was measured next to each collar at 2 and $10 \mathrm{~cm}$ depth (Fluke $51 \mathrm{II}$ Thermometer (Wilmingtion, NC, USA)). A soil core $(1.5 \mathrm{~cm}$ diameter) was extracted next to each collar following the $\mathrm{NO}_{\mathrm{x}}$ measurement $(0-10 \mathrm{~cm})$. The core was homogenized in a bag before removing $15 \mathrm{~g}$ for measuring soil volumetric water content and $2.5 \mathrm{~g}$ for inorganic $\mathrm{N}$ extraction at a 1:10 soil weight-to-solution volume ratio using $2 \mathrm{M} \mathrm{KCl}$. Extracts were put on ice until transported back to the lab, where they were processed within $24-48 \mathrm{~h}$. Samples were shaken for $1 \mathrm{~h}$ at room temperature, centrifuged and filtered through Whatman no. 40 filter paper $(11 \mu \mathrm{m})$ and frozen until further processing. Filtrates were acidified and analysed by automated cadmium coil reduction for nitrate/nitrite (Seal Analytical Inc., AQ2 Discrete Analyzer (Mequon, Wisconsin). $\mathrm{NO}_{3}$ and $\mathrm{NH}_{4}$ are expressed in $\mu \mathrm{g} \mathrm{N} \mathrm{g}^{-1}$ dry soil.

Statistical analyses. In a comprehensive analysis of all observed $\mathrm{NO}_{\mathrm{x}}$ fluxes, nonlinear generalized additive modelling was used to assess the influence of environmental parameters on $\mathrm{NO}_{\mathrm{x}}$ flux via the GAM function in $\mathrm{R}$ (v.3.1.1, Vienna, Austria). The model included explanatory variables $\mathrm{NO}_{3}, \mathrm{NH}_{4}$, soil temperature (averaged between 2 and $10 \mathrm{~cm}$ depth), soil volumetric water content (averaged across $0-10 \mathrm{~cm}$ depth) and days since fertilization. The best-fitting parsimonious model was selected using Akaike's information criterion. For visualization, $\mathrm{NO}_{\mathrm{x}}$ fluxes were binned according to environmental variables (days since fertilization, soil volumetric water content and soil temperature). Third-order polynomials were fitted to the relationships between binned average $\mathrm{NO}_{\mathrm{x}}$ flux and soil volumetric water content and soil temperature. A Gaussian equation was fitted to the relationship between binned average $\mathrm{NO}_{\mathrm{x}}$ flux and days since fertilization. All fitting was performed in Matlab (v.R2014a, The Mathworks, Inc. USA). Repeated measures analyses of variance were conducted independently on each $\mathrm{N}$-fertilization experiment to test for significant effects of treatment (fertilized or control) on $\mathrm{NO}_{\mathrm{x}}$ emissions. Pairwise comparisons using the Bonferroni adjustment were conducted to explore differences between treatments at specific time points. $\mathrm{NO}_{\mathrm{x}}$ emissions were log transformed to meet homogeneity of variance assumptions. Analysis of variance and Bonferroni tests were performed in R (v.3.1.1, Vienna, Austria). To estimate total $\mathrm{N}$ released as $\mathrm{NO}_{\mathrm{x}}$ in response to treatments, we performed numerical integration via the trapezoidal method in Matlab. These integrated values are only approximate and are most likely an underestimate of total flux, as peak fluxes may not have been captured with discontinuous measurement techniques.

Regional air quality modelling. We evaluated the influence of soil $\mathrm{NO}_{\mathrm{x}}$ emissions on regional air quality using the WRF-Chem (version 2.0). The WRF-Chem model $^{29,43}$ is a regional air quality model that can be used for weather forecasting and simulating gas-phase chemistry, including $\mathrm{NO}_{\mathrm{x}}$ and ozone chemistry at an hourly time step. With its nested grid capability, WRF-Chem-simulated quantities can be more easily compared with a wide range of in situ and remote sensing data

\section{Table 1 | WRF-Chem configuration.}

\section{Atmospheric process/inputs}

Surface layer

Land surface

Boundary layer

Cumulus clouds

Cloud microphysics

Gas-phase chemistry

Aerosol chemistry

Horizontal resolution

Vertical layers

Model option

WRF-Chem, Weather Research and Forecasting with Chemistry model.

collected at different temporal and spatial resolutions. A nested grid configuration was used in this study with the centre in the Imperial Valley, CA. The resolution of fine grid was $12 \times 12 \mathrm{~km}$ and the outer domain was $36 \times 36 \mathrm{~km}$. Table 1 lists the model configuration options employed in this study.

The NARR (North American Regional Reanalysis) data at 0000, 0600, 1200 and 1800 UTC were used for initializing and specifying the temporally evolving lateral boundary conditions. The US National Emissions Inventory emissions data (NEI-05; version 2) was used in the simulation as background emission (US Environmental Protection Agency, 2010). The NEI-05 data are likely a high estimate for anthropogenic $\mathrm{NO}_{\mathrm{x}}$ sources in the Imperial Valley. Previous work in Los Angeles County has shown that anthropogenic $\mathrm{NO}_{\mathrm{x}}$ sources in NEI-05 are overestimated by $32 \%$ (ref. 30). The land-use data used in this study is the US Geological Survey land-use data. Biogenic emissions of volatile organic compounds and soil $\mathrm{NO}_{\mathrm{x}}$ emissions are calculated using the Model of Emissions of Gases and Aerosols from Nature (MEGAN v2.0 (refs 44,45)). In MEGAN, gridded emission factors are based on global data sets of four functional plant types (broadleaf trees, needle-leaf tree, shrubs/bushes and herbs/crops/grasses), where the herbs/crops/ grass category has a higher emission factor compared with the other plant types ${ }^{46}$. In this version of MEGAN, soil $\mathrm{N}\left(\mathrm{NO}, \mathrm{NO}_{2}\right.$ and $\left.\mathrm{NH}_{3}\right)$ emissions are a function of temperature only; production and loss of $\mathrm{NO}_{\mathrm{x}}$ within the canopy is not considered. Previously reported canopy uptake rates are low, ranging up to $3 \mathrm{ng} \mathrm{N}-\mathrm{NO}_{2} \mathrm{~m}^{-2} \mathrm{~s}^{-1}$ under high light and high $\mathrm{NO}_{2}$ concentrations $\left(\mathrm{NO}_{2}=5 \text { p.p.b. }\right)^{47}$. However, canopy uptake rates in high-emission and hightemperature environments are uncertain and require further research ${ }^{36,47-50}$. Pulse $\mathrm{NO}_{\mathrm{x}}$ emissions following fertilization events are also not considered in the model. The emission factor for agricultural soils is $6 \mathrm{ng} \mathrm{N} \mathrm{m}^{-2} \mathrm{~s}^{-1}$ at a standard temperature of $273.15 \mathrm{~K}$ (ref. 46). Due to assumptions made in the satellite observations, we apply an averaging kernel to the WRF-Chem simulations to allow comparison with the space-borne OMI (described below) $)^{51,52}$.

Modifications to a regional air quality model. To evaluate the sensitivity of air quality to soil $\mathrm{NO}_{2}$ sources in the Imperial Valley, we modified the strength of soil $\mathrm{NO}_{\mathrm{x}}$ emissions from irrigated agricultural land. Other land types such as surrounding urban and dry native lands were not manipulated. We elevated WRFChem emission rates by a factor of 10 and 64.5, resulting in simulated soil $\mathrm{NO}_{\mathrm{x}}$ emissions in Imperial Valley croplands near 20 and $129 \mathrm{ng} \mathrm{N} \mathrm{m}^{-2} \mathrm{~s}^{-1}$, which are representative of the range in mean and median flux values collected under both average and recently fertilized conditions in the field. It is important to note that this modelling exercise simply increases emission rates and does not account for the observed nonlinear pulse $\mathrm{NO}_{\mathrm{x}}$ emission events that occur in response to fertilization.

All simulations were run for 7 days in September 2012 (23-29 September 2012), with several days as spin-up time. These simulations were compared with measurements of surface and tropospheric $\mathrm{NO}_{2}$ columns above the Imperial Valley.

Comparing modelled and measured $\mathbf{N O}_{\mathbf{2}}$. Evaluation of WRF-Chem model performance was assessed through comparisons with surface and satellite observations. First, we compared modelled with measured surface $\mathrm{NO}_{2}$ in the Imperial Valley. Surface $\mathrm{NO}_{2}$ concentrations are measured by the California Air Resources Board at an air quality-monitoring site located $11.3 \mathrm{~km}$ west of DREC on 9th Street, El Centro, CA (latitude: 32.79222; longitude: - 115.563). This site is not near a point source and provides representative concentrations of pollutants for the Imperial Valley. Surface $\mathrm{NO}_{2}$ measurements are made by first reducing all $\mathrm{NO}_{2}$ to NO using heated molybdenum surfaces and then measuring the chemiluminescent reaction of $\mathrm{NO}$ with $\mathrm{O}_{3}$ (ref. 53). Comparisons between modelled and measured surface $\mathrm{NO}_{2}$ concentration were made for all WRF-Chem model simulations 
(default, $10 \times$ and $64.5 \times$ elevated soil $\mathrm{NO}_{\mathrm{x}}$ emission). WRF-Chem model performance was assessed using linear regression and the coefficient of determination $\left(r^{2}\right)$. Model bias was estimated using the absolute r.m.s.e. between modelled and observed surface $\mathrm{NO}_{2}$ concentrations.

To evaluate the model's ability to simulate local meteorology, we compared daily average wind speed $\left(\mathrm{m} \mathrm{s}^{-1}\right)$ and air temperature $\left({ }^{\circ} \mathrm{C}\right)$ measured at the El Centro air quality monitoring station and simulated by the model. Model performance was assessed using the coefficient of determination $\left(r^{2}\right)$ and the absolute r.m.s.e.. We evaluated local sources of $\mathrm{NO}_{\mathrm{x}}$ from biomass-burning events using MODIS images. MODIS images are publically available and were assessed for 20-29 September 2012. We also analysed meteorological data from a weather station located at DREC (managed by the California Irrigation Management Information System, www.cimis.water.ca.gov) to investigate how rainfall ( $\mathrm{mm})$, air temperature $\left({ }^{\circ} \mathrm{C}\right)$ and net radiation $\left(\mathrm{W} \mathrm{m}^{-2}\right)$ changed during the simulation period.

We also assess WRF-Chem performance using remotely sensed tropospheric columnar $\mathrm{NO}_{2}$ by OMI on board the Aura satellite. OMI measures radiation in the broad visible spectrum between 264 and $504 \mathrm{~nm}^{54}$. OMI has near daily contiguous global coverage with moderate spatial resolution (60 cross-track ground pixels ranging from $13 \times 24$ to $128 \times 40 \mathrm{~km}$ at the edge of a sampling swath). We use the level 2 (version 2.0) KNMI-DOMINO product (Royal Netherlands Meteorological Institute). The KNMI product and its errors are described in detail by Irie et al..$^{55}$ and Boersma et al. ${ }^{56,57}$. Briefly, the KNMI-DOMINO product determines the stratospheric portion of the column by assimilating slant columns in the TM4 chemistry transport model, with an uncertainty in the stratospheric $\mathrm{NO}_{2}$ column of near $0.3^{*} 10^{15}$ molecules per $\mathrm{cm}^{2}$ (ref. 58). The tropospheric air mass factor is determined using the formulation of Palmer et al. ${ }^{59}$ and Boersma et al ${ }^{60}$ to convert slant columns to vertical columns ${ }^{57}$. The KNMI product is known to compare well with aircraft measurements of $\mathrm{NO}_{2}$ in urban regions $\left(r^{2}=0.67\right.$, slope $=0.99 \pm 0.17)^{61}$, while tending to overestimate $\mathrm{NO}_{2}$ in remote regions ${ }^{62,63}$. When compared with ground-based measurements in China, the biases of the KNMI product were less than $10 \%$ (ref. 55). The KNMI product is also known to have less systematic seasonal error compared with the NASA product ${ }^{52}$. Due to satellite data having irregular grid boxes, we re-gridded to regular grid boxes at a $0.4^{\circ}$ resolution using area-weighted average for illustrative purposes (Fig. 6). During the WRF-Chem simulation period, an average of eight OMI pixels fell within the Imperial Valley region. We present OMI data averaged across 25,28 and 29 September 2012, as these were all days during the WRF-Chem simulation period when OMI data were available, the cloud radiance fraction was $<50 \%$ and the target region was not on the edge of the swath (excluding pixels with a viewing angle $>45^{\circ}$ ).

\section{References}

1. Field, C. B. et al. Climate Change 2014: Impacts, Adaptation, and Vulnerability. Part A: Global and Sectoral Aspects. Contribution of Working Group II to the Fifth Assessment Report of the Intergovernmental Panel on Climate Change. (Cambridge, UK and New York, USA, 2014).

2. Hall, S. J., Matson, P. A. \& Roth, P. M. $\mathrm{NO}_{\mathrm{x}}$ emissions from soil: implications for air quality modeling in agricultural regions. Annu. Rev. Energ. Environ. 21, 311-346 (1996).

3. Peel, J. L., Haeuber, R., Garcia, V., Russell, A. G. \& Neas, L. Impact of nitrogen and climate change interactions on ambient air pollution and human health. Biogeochemistry 114, 121-134 (2013).

4. Hall, S. J., Huber, D. \& Grimm, N. B. Soil $\mathrm{N}_{2} \mathrm{O}$ and $\mathrm{NO}$ emissions from an arid, urban ecosystem. J. Geophys. Res. 113, G01016 (2008).

5. Bouwman, A. F., Boumans, L. J. M. \& Batjes, N. H. Emissions of N2O and NO from fertilized fields: summary of available measurement data. Glob. Biogeochem. Cycle 16, 6.1-6.13 (2002).

6. Schindlbacher, A., Zechmeister-Boltenstern, S. \& Butterbach-Bahl, K. Effects of soil moisture and temperature on $\mathrm{NO}, \mathrm{NO}_{2}$, and $\mathrm{N}_{2} \mathrm{O}$ emissions from European forest soils. J. Geophys. Res. 109, D17302 (2004).

7. Davidson, E. A. et al. Soil emissions of nitric oxide in a seasonally dry tropical forest of Mexico. J. Geophys. Res. Atmos. 96, 15439-15445 (1991).

8. Steinkamp, J. \& Lawrence, M. G. Improvement and evaluation of simulated global biogenic soil NO emissions in an AC-GCM. Atmos. Chem. Phys. 11, 6063-6082 (2011).

9. Hudman, R. C. et al. Steps towards a mechanistic model of global soil nitric oxide emissions: implementation and space based-constraints. Atmos. Chem. Phys. 12, 7779-7795 (2012).

10. Vinken, G., Boersma, K., Maasakkers, J., Adon, M. \& Martin, R. Worldwide biogenic soil $\mathrm{NO}_{\mathrm{x}}$ emissions inferred from $\mathrm{OMI} \mathrm{NO}_{2}$ observations. Atmos. Chem. Phys. 14, 10363-10381 (2014).

11. Garfin, G. et al. in Climate Change Impacts in the United States: The Third National Climate Assessment (eds Melillo, J., Richmond, T., \& Yohe, G.) 462-486 (US Global Change Research Program, 2014).

12. Hoerling, M. P. et al. Assessment of Climate Change in the Southwest United States 74-100 (Springer, 2013).

13. Diffenbaugh, N. S., Giorgi, F. \& Pal, J. S. Climate change hotspots in the United States. Geophys. Res. Lett. 35 (2008).
14. EPA. Current Nonattainment Counties for all Criteria Pollutants. Green Book. Available at http://www.epa.gov/oaqps001/greenbk/ancl.html, last accessed July 2015 (2014).

15. Stockman, J. K., Shaikh, N., Von Behren, J., Bembom, O. \& Kreutzer, R. California County Asthma Hospitalization Chart Book: Data from 1998-2000 (Department of Health Services, Environmental Health Investigations Branch, 2003).

16. Jacob, D. Introduction to Atmospheric Chemistry (Princeton Univ. Press, 1999).

17. Hudman, R. C., Russell, A. R., Valin, L. C. \& Cohen, R. C. Interannual variability in soil nitric oxide emissions over the United States as viewed from space. Atmos. Chem. Phys. 10, 9943-9952 (2010).

18. Saad, O. \& Conrad, R. Temperature-dependence of nitrification, denitrification, and turnover of nitric-oxide in different soils. Biol. Fertil. Soils 15, 21-27 (1993).

19. Gödde, M. \& Conrad, R. Immediate and adaptational temperature effects on nitric oxide production and nitrous oxide release from nitrification and denitrification in two soils. Biol. Fertil. Soils 30, 33-40 (1999).

20. Maag, M. \& Vinther, F. P. Nitrous oxide emission by nitrification and denitrification in different soil types and at different soil moisture contents and temperatures. Appl. Soil Ecol. 4, 5-14 (1996).

21. Ghude, S. D. et al. $\mathrm{NO}_{\mathrm{x}}$ emission from India during the onset of the summer monsoon: a satellite perspective. J. Geophys. Res. 115, D16304 (2010).

22. Harris, G. W., Wienhold, F. G. \& Zenker, T. Airborne observations of strong biogenic $\mathrm{NO}_{\mathrm{x}}$ emissions from the Namibian savanna at the end of the dry season. J. Geophys. Res. 101, 23707-23711 (1996).

23. Bertram, T. H., Heckel, A., Richter, A., Burrows, J. P. \& Cohen, R. C. Satellite measurements of daily variations in soil $\mathrm{NO}_{\mathrm{x}}$ emissions. Geophys. Res. Lett. 32, L24812 (2005).

24. Yienger, J. J. \& Levy, H. Empirical model of global soil-biogenic $\mathrm{NO}_{\mathrm{x}}$ emissions. J. Geophys. Res. Atmos. 100, 11447-11464 (1995).

25. Tian, H. et al. Spatial and temporal patterns of $\mathrm{CH}_{4}$ and $\mathrm{N}_{2} \mathrm{O}$ fluxes in terrestrial ecosystems of North America during 1979-2008: application of a global biogeochemistry model. Biogeosciences 7, 2673-2694 (2010).

26. Li, C. \& Aber, J. A process-oriented model of N20 and NO. J. Geophys. Res. 105, 4369-4384 (2000).

27. Jaeglé, L., Steinberger, L., Martin, R. V. \& Chance, K. Global partitioning of $\mathrm{NO}_{\mathrm{x}}$ sources using satellite observations: relative roles of fossil fuel combustion, biomass burning and soil emissions. Faraday Discuss. 130, 407-423 (2005).

28. Potter, C. S., Matson, P. A., Vitousek, P. M. \& Davidson, E. A. Process modeling of controls on nitrogen trace gas emissions from soils worldwide. J. Geophys. Res. Atmos. 101, 1361-1377 (1996).

29. Grell, G. A. et al. Fully coupled 'online' chemistry within the WRF model. Atmos. Environ. 39, 6957-6975 (2005)

30. Brioude, J. et al. Top-down estimate of surface flux in the Los Angeles Basin using a mesoscale inverse modeling technique: assessing anthropogenic emissions of $\mathrm{CO}, \mathrm{NO}_{\mathrm{x}}$ and $\mathrm{CO}_{2}$ and their impacts. Atmos. Chem. Phys. 13, 3661-3677 (2013).

31. Matson, P. A., Naylor, R. \& Ortiz-Monasterio, I. Integration of environmental, agronomic, and economic aspects of fertilizer management. Science $\mathbf{2 8 0}$, 112-115 (1998).

32. Thornton, F. C., Bock, B. R. \& Tyler, D. D. Soil emissions of nitric oxide and nitrous oxide from injected anhydrous ammonium and urea. J. Environ. Qual. 25, 1378-1384 (1996).

33. Wang, Y., Jacob, D. J. \& Logan, J. A. Global simulation of tropospheric $\mathrm{O}_{3}-\mathrm{NO}_{\mathrm{x}}$-hydrocarbon chemistry: 1. Model formulation. J. Geophys. Res. Atmos 103, 10713-10725 (1998).

34. Oikawa, P. Y. et al. Unifying soil respiration pulses, inhibition, and temperature hysteresis through dynamics of labile soil carbon and $\mathrm{O}_{2}$. J. Geophys. Res. 119, 521-536 (2014).

35. Sindelarova, K. et al. Global data set of biogenic VOC emissions calculated by the MEGAN model over the last 30 years. Atmos. Chem. Phys. 14, 9317-9341 (2014).

36. Oikawa, P. Y., Jenerette, G. D. \& Grantz, D. A. Offsetting high water demands with high productivity: Sorghum as a biofuel crop in a high irradiance arid ecosystem. GCB Bioenergy 7, 974-983 (2015).

37. Resources CDoW. Irrigated Crop Acres and Water Use. Available at http://www.water.ca.gov/landwateruse/anaglwu.cfm, last accessed July 2015 (2010).

38. Wright, S. D., Collar, C. A., Klonsky, K. \& De Moura, R. L. Sample Costs to Produce Sorghum Silage. http://coststudyfiles.ucdavis.edu/uploads/cs_public/f8/ b1/f8b125ac-f70c-42ff-97d2-4caa93121510/sudansilagevs09.pdf (Extension UoCC, 2009)

39. Mayberry, K. S. Sample Cost to Establish and Produce Sudangrass http:// coststudyfiles.ucdavis.edu/uploads/cs_public/a2/ba/a2ba6644-27fc-4e2a-b70e-611 d9c23d636/sudangrass04.pdf, last accessed October 2015 (Extension UoCC, 2000).

40. Jackson, L., Fernandez, B., Meister, H. \& Spiller, M. Small grain production manual 8164 (University of California Division of Agriculture and Natural Resources, 2006). 
41. California Department of Water Resources. http://www.water.ca.gov/ landwateruse/surveys.cfmStatewide Irrigation Methods Survey (2010).

42. Parkin, T. B. \& Venterea, R. T. in Sampling Protocols (ed. Follett, R. F.) 3-1 to 3-39. Available at www.ars.usda.gov/research/GRACEnet (USDA-ARS, 2010).

43. Fast, J. D. et al. Evolution of ozone, particulates, and aerosol direct radiative forcing in the vicinity of Houston using a fully coupled meteorology-chemistryaerosol model. J. Geophys. Res. Atmos. 111, D21305 (2006).

44. Guenther, A. et al. Estimates of global terrestrial isoprene emissions using MEGAN (Model of Emissions of Gases and Aerosols from Nature). Atmos. Chem. Phys. 6, 3181-3210 (2006).

45. Guenther, A. et al. The model of emissions of gases and aerosols from nature version 2.1 (MEGAN2. 1): an extended and updated framework for modeling biogenic emissions Geosci. Model Dev. 5, 1471-1492 (2012).

46. Grell, G. A. et al. Application of a multiscale, coupled MM5/chemistry model to the complex terrain of the VOTALP valley campaign. Atmos. Environ. 34, 1435-1453 (2000).

47. Chaparro-Suarez, I., Meixner, F. \& Kesselmeier, J. Nitrogen dioxide $\left(\mathrm{NO}_{2}\right)$ uptake by vegetation controlled by atmospheric concentrations and plant stomatal aperture. Atmos. Environ. 45, 5742-5750 (2011).

48. Raivonen, M. et al. Compensation point of $\mathrm{NO}_{\mathrm{x}}$ exchange: Net result of $\mathrm{NO}_{\mathrm{x}}$ consumption and production. Agric. For. Meteorol. 149, 1073-1081 (2009).

49. Hereid, D. P. \& Monson, R. K. Nitrogen oxide fluxes between corn (Zea mays L.) leaves and the atmosphere. Atmos. Environ. 35, 975-983 (2001).

50. Teklemariam, T. A. \& Sparks, J. P. Leaf fluxes of $\mathrm{NO}$ and $\mathrm{NO}_{2}$ in four herbaceous plant species: the role of ascorbic acid. Atmos. Environ. 40, 2235-2244 (2006).

51. Eskes, H. \& Boersma, K. Averaging kernels for DOAS total-column satellite retrievals. Atmos. Chem. Phys. 3, 1285-1291 (2003).

52. Herron-Thorpe, F., Lamb, B., Mount, G. \& Vaughan, J. Evaluation of a regional air quality forecast model for tropospheric $\mathrm{NO}_{2}$ columns using the $\mathrm{OMI} /$ Aura satellite tropospheric $\mathrm{NO}_{2}$ product. Atmos. Chem. Phys. 10, 8839-8854 (2010).

53. Demerjian, K. L. A review of national monitoring networks in North America. Atmos. Environ. 34, 1861-1884 (2000).

54. Levelt, P. F. et al. The ozone monitoring instrument. IEEE Trans. Geosci. Remote Sensing 44, 1093-1101 (2006).

55. Irie, H. et al. First quantitative bias estimates for tropospheric $\mathrm{NO}_{2}$ columns retrieved from SCIAMACHY, OMI, and GOME-2 using a common standard. Atmos. Meas. Tech. 5, 3953-3971 (2012).

56. Boersma, K. et al. Near-real time retrieval of tropospheric $\mathrm{NO}_{2}$ from OMI. Atmos. Chem. Phys. 7, 2103-2118 (2007).

57. Boersma, K. et al. An improved tropospheric $\mathrm{NO}_{2}$ column retrieval algorithm for the Ozone Monitoring Instrument. Atmos. Meas. Tech. 4, 1905-1928 (2011).

58. Dirksen, R. J. et al. Evaluation of stratospheric $\mathrm{NO}_{2}$ retrieved from the Ozone Monitoring Instrument: intercomparison, diurnal cycle, and trending. J. Geophys. Res. Atmos. 116, D08305 (2011).

59. Palmer, P. I. et al. Air mass factor formulation for spectroscopic measurements from satellites: application to formaldehyde retrievals from the Global Ozone Monitoring Experiment. J. Geophys. Res. Atmos. 106, 14539-14550 (2001).

60. Boersma, K., Eskes, H. \& Brinksma, E. Error analysis for tropospheric $\mathrm{NO}_{2}$ retrieval from space. J. Geophys. Res. Atmos. 109, D04311 (2004).

61. Boersma, K. et al. Validation of OMI tropospheric $\mathrm{NO}_{2}$ observations during INTEX-B and application to constrain $\mathrm{NO}_{\mathrm{x}}$ emissions over the eastern United States and Mexico. Atmos. Environ. 42, 4480-4497 (2008).

62. Bucsela, E. et al. Comparison of tropospheric $\mathrm{NO}_{2}$ from in situ aircraft measurements with near-real-time and standard product data from OMI. $J$. Geophys. Res. Atmos. 113, D16S31 (2008).

63. Russell, A. et al. A high spatial resolution retrieval of $\mathrm{NO}_{2}$ column densities from OMI: method and evaluation. Atmos. Chem. Phys. 11, 8543-8554 (2011).
64. Chen, F. \& Dudhia, J. Coupling an advanced land surface-hydrology model with the Penn State-NCAR MM5 modeling system. Part I: model implementation and sensitivity. Mon. Weather Rev. 129, 569-585 (2001).

65. Hong, S.-Y., Noh, Y. \& Dudhia, J. A new vertical diffusion package with an explicit treatment of entrainment processes. Mon. Weather Rev. 134, 2318-2341 (2006).

66. Grell, G. A. \& Dévényi, D. A generalized approach to parameterizing convection combining ensemble and data assimilation techniques. Geophys. Res. Lett. 29, 38-31-38-34 (2002).

67. Lin, Y.-L., Farley, R. D. \& Orville, H. D. Bulk parameterization of the snow field in a cloud model. J. Clim. Appl. Meteorol. 22, 1065-1092 (1983).

68. Stockwell, W. R., Middleton, P., Chang, J. S. \& Tang, X. The second generation regional acid deposition model chemical mechanism for regional air quality modeling. J. Geophys. Res. Atmos. 95, 16343-16367 (1990).

69. Ackermann, I. J. et al. Modal aerosol dynamics model for Europe: Development and first applications. Atmos. Environ. 32, 2981-2999 (1998).

70. Schell, B., Ackermann, I. J., Hass, H., Binkowski, F. S. \& Ebel, A. Modeling the formation of secondary organic aerosol within a comprehensive air quality model system. J. Geophys. Res. Atmos. 106, 28275-228293 (2001).

\section{Acknowledgements}

We are grateful to F. Miramontes and F. Maciel and the staff of the University of California Desert Research and Extension Center for skillful assistance, to K. Kitajima, P. Homyak and M. Bell for technical advice, and K. Ricio, A. Contreras and many other dedicated undergraduates for field and laboratory assistance. We thank Robert Johnson for map preparation. We thank Coby Kriegshauser at Scott Seed Co. for providing seeds for these experiments. We thank anonymous reviewers for their helpful comments and suggestions. Participation of C.G. and J.W. was supported by NASA Applied Science Program and Aura Science program, and by Holland Computing Center and Office for Research and Economic Development in University of Nebraska-Lincoln. This work was also supported by the USDA-NIFA Award No. 2011-67009-30045, and by U.C. Riverside.

\section{Author contributions}

This experiment was designed and implemented by all authors. P.Y.O., G.D.J., D.A.G., L.A.A., L.L.L. and J.R.E. participated in the collection of data at the University of California Desert Research and Extension Center. J.W. and C.G. conducted all WRF-Chem simulations and retrieval of OMI data. All authors contributed to data analysis and editing and revisions of text.

\section{Additional information}

Supplementary Information accompanies this paper at http://www.nature.com/ naturecommunications

Competing financial interests: The authors declare no competing financial interests.

Reprints and permission information is available online at http://npg.nature.com/ reprintsandpermissions/

How to cite this article: Oikawa, P. Y. et al. Unusually high soil nitrogen oxide emissions influence air quality in a high-temperature agricultural region. Nat. Commun. 6:8753 doi: $10.1038 /$ ncomms 9753 (2015).

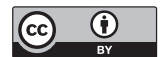

This work is licensed under a Creative Commons Attribution 4.0 International License. The images or other third party material in this article are included in the article's Creative Commons license, unless indicated otherwise in the credit line; if the material is not included under the Creative Commons license, users will need to obtain permission from the license holder to reproduce the material. To view a copy of this license, visit http://creativecommons.org/licenses/by/4.0/ 